\title{
Finding the Right Partner: Rural Homogamy in Nineteenth-Century Sweden*
}

\author{
Martin Dribe AND Christer LundH
}

Summary: In pre-industrial society, choosing a marriage partner was a crucial process, and especially so for landowners. This study focuses on social aspects of mate selection in five rural parishes in southern Sweden between I 829 and I 894, using an individual-level database containing information on a large number of marriages and the social origins of the marrying couple regardless of whether they were born in the relevant parish or not. The information makes it possible to study homogamy without introducing the possible selection biases implicit in looking only at non-migrating population, a consideration which is of great importance in a society characterized by very high levels of geographical mobility. The results show a community marked by quite strong homogamy but with pronounced differences among social groups. Landholding peasants were the most homogamous. The pattern of homogamy also remained fairly constant despite fundamental economic and social change.

\section{INTRODUCTION}

In pre-industrial western Europe there was great importance attached to the economic aspects of marriage. In areas dominated by the western European marriage pattern, marriage was closely connected to family and household formation: ${ }^{\mathrm{I}}$ in order to marry, a young couple needed a secure income and accommodation to be able to set up an independent household. To peasants, access to land was vital, and marriage was often inextricably linked to intergenerational land transmission, which made the

\footnotetext{
* An earlier version of this article was presented at the 5 th European Social Science History Conference (Berlin, 24-27 March 2004). We are grateful to Antoinette Fauve-Chamoux, Bart Van de Putte, Patrick Svensson, and the editors of this issue for comments and suggestions. Martin Dribe gratefully acknowledges financial support from the Swedish Council for Working Life and Social Research (FAS). Christer Lundh's research was undertaken as part of the projects "Age at Marriage in Sweden 1750- 1900: Trends and Regional Variations", funded by the Swedish Council for Research in the Humanities and Social Science (HSFR), and "Early-Life Conditions, Social Mobility, and Longevity: Social Differences and Trends in Mortality in Sweden, 1650-1900", funded by the Swedish Council for Working Life and Social Research (FAS).

I. John Hajnal, "European Marriage Patterns in Perspective", in D.V. Glass and D.E.C. Eversley (eds), Population in History. Essays in Historical Demography (London, I965), pp. IOI-I43; idem, "Two Kinds of Pre-industrial Household Formation System", in Richard Wall, Jean Robin, and Peter Laslett (eds), Family Forms in Historic Europe (Cambridge, 1983), pp. 65 -104.
} 
choice of marriage partner a crucial issue and one in which a lot more than love and affection was involved. ${ }^{2}$ In addition to this important financial aspect, marriage constituted a method of linking lineages. Kinship alliance in itself could be an important motive for marriage, or it could be used as an instrument to find a socially and financially suitable partner in the marriage market, ${ }^{3}$ so marriage strategies were closely tied to more general family strategies regarding social reproduction, where marriage was intimately connected to concerns about inheritance, land transmission, migration decisions, and so on. ${ }^{4}$

The aim of this article is to analyse social homogamy in a rural area of southern Sweden from I829-I894. Our starting point is the claim of ethnologists and local historians that pre-industrial rural society was indeed characterized by a rather strong tendency to homogamy. Although such claims make sense in the light of what we have just seen, they are based mostly on qualitative sources or individual examples which show the occurrence of positive assortative mating (people with similar characteristics marrying each other), but not its frequency. The approach in this study will be to confront the picture given by ethnologists and local historians with demographic data, and so to undertake a quantitative analysis of the frequency of homogamy. More specifically, we shall ask if there was a general tendency to homogamy in rural areas of southern Sweden in the nineteenth century, and if it was similarly the case across social groups and over time.

In order to answer such questions we make use of a high-quality dataset based on family reconstitutions of five rural parishes in the province of Scania in southern Sweden. By tracing back to their place of birth all individuals living in a marital union in one of these parishes during the period I 829-I894, we create the opportunity to study social homogamy without introducing possible selection biases stemming from migration, which are otherwise common in family reconstitution studies.

\section{B A C K GROUND}

If marriage were just an act of love and mate selection not restricted by institutions along social, religious, or ethnic lines or by geographic

2. See Lawrence Stone, The Family, Sex and Marriage in England I500-I800 (London, 1979), especially ch. 7; Michael Mitterauer and Reinhard Sieder, The European Family (Chicago, IL, I982), ch. 6.

3. Joseph Ehmer, "Marriage", in David I. Kertzer and Marzio Barbagli (eds), Family Life In the Long Nineteenth Century 1789-1913 (New Haven, CT [etc.], 2002), pp. 282-321; David W. Sabean, Kinship in Neckarhausen, $1700-1870$ (Cambridge, I998).

4. See Pierre Bourdieu, "Marriage Strategies as Strategies of Social Reproduction", in Robert Forster and Orest Ranum (eds), Family and Society: Selections from the Annales, Économies, Sociétés, Civilisations (Baltimore, MD, 1976), pp. I 17-144. 
distance, the mix of mates into couples would be rather haphazard. For many reasons we know that this is not how marriage worked in olden times, nor does it today. Therefore, theories have been developed in order to explain individuals' assortative behaviour in the marriage market.

One line of argument is that mate selection aims at pooling wealth and status from two households into a third, new union.5 Certain marriage strategies are developed in order to maximize the outcome of such unions depending on the social, religious, or ethnic origin of the spouses. For financial reasons, and for fear of punishment from family and social, or religious and ethnic groups, young people will prefer a spouse with similar economic characteristics - in accordance with the saying "birds of a feather flock together".

In economic theories of marriage it is considered that the assortative mating process is largely determined by the gender division of labour, the productivity (wage) of men and women in different tasks, and the effects of different time allocations on aggregate output in household production, i.e. whether spouses have similar characteristics (positive assortative mating) or different ones (negative assortative mating). ${ }^{6}$ However, in a pre-industrial rural context mating has less to do with divisions of labour than with assets, and mainly with access to land and housing. Regardless of whether spouses were similar in terms of assets, they were always specialists in different jobs of work in accordance with the gender-based division of labour. ${ }^{7}$ That implies that gains in specialization were not the point in different matches. Instead, strategies aimed at maintaining family estates and securing a viable landholding and social reproduction lay at the centre of the marriage decision, at least for landed groups.

In nineteenth-century southern Sweden people were homogeneous as far as religion and ethnicity were concerned but they were divided socially. There were many institutions in rural society, some connected to marriage, which make it reasonable to believe that certain marriage strategies were practised, especially among landholding peasants. For example, we know

5. See Matthijs Kalmijn, "Intermarriage and Homogamy: Causes, Patterns and Trends", Annual Review of Sociology, 24 (1998), pp. 395-42 I. On the other hand, people of lower status could make a social career through marriage, thereby increasing their wealth and status. By marrying a peasant head of household, a maid would immediately improve her position to that of mistress and supervisor of the female servants. A corresponding union between a farmhand and a farmer's daughter would mean a social career to the former, who would become the head of household, the guardian of his wife, and the manager of the farm. Though such cases were few (see Christer Lundh, "Remarriages in Sweden in the Eighteenth and Nineteenth Centuries", History of the Family, 7 (2002), pp. 423-450), they would counteract the tendency to homogamy.

6. Gary S. Becker, A Treatise on the Family (enlarged edn, Cambridge, MA, I99I), ch. 4.

7. See Orvar Löfgren, "Family and Household among Scandinavian Peasants: An Exploratory Essay”, Ethnologia Scandinavica, 4 (1974), pp. 17-52; idem, Arbetsfördelning och könsroller $i$ bondesambället - kontinuitet och förändring (Lund, 1977); Louise A. Tilly and Joan W. Scott, "Women's Work and the Family in Nineteenth Century Europe", Comparative Studies in Society and History, 17 (1975), pp. 36-64. 
that peasant couples developed various techniques to modify the principle of inheritance legislation, which prescribed equal inheritance among all children. ${ }^{8}$ In Scania, the most common way seems to have been to transfer the family farm to a chosen child, often the eldest son, while at least one parent was still alive, in exchange for board and lodging for life. This was known as "peasant retirement". ${ }^{9}$ However, it was not always the eldest son who became the new manager of the family farm, for quite often a younger son took on the job; or a daughter, which meant in fact a son-in-law. ${ }^{10}$ To choose the right person must have been a crucial decision for the ageing couple: children who were not favoured in this respect were compensated in other ways, by parcels of land or movable property. ${ }^{\text {II }}$

It is easy to imagine that the marriage of children played an important role for the peasant couple in their plans for their own old age and succession between generations. The splitting of land through inheritance could be compensated for by the right marriage arrangement. A successful union between one of the children and a similarly wealthy party was a guarantee that the farm could maintain two households when the old couple retired. Beside the fact that they owned, and managed, the family farm, the institution of marriage gave the ageing couple an important role in the mating process.

According to the Marriage Act of 1734 , no-one could be forced into marriage, and that applied both to men and women. On the other hand, the same act included provisions giving parents the power to influence their

8. Under Swedish inheritance legislation all children inherited from their parents. Up to i 845 , sons inherited twice the amount that daughters did, but from i 845 all children inherited equally. Despite this general rule, the parents could to some extent favour one chosen child by separately bequeathing movable property or plots of newly acquired land. Even though all children had the right to their lawful portion, they could not always count on inheriting land. In cases where the farm was too small to divide, an heir with a larger share could buy out the others. This rule was valid up to I845; after that a brother could buy out a sister. For a general description of the Swedish inheritance system, see Christer Winberg, "Familj och jord i tre västgötasocknar. Generationsskiften bland självägande bönder ca I8 10-1870", Historisk tidskrift, I0 I (1981), pp. 278-310, and Martin Dribe and Christer Lundh, "Gender Aspects of Inheritance Strategies and Land Transmission in Rural Scania, Sweden, I720-I840", in Emiko Ochiai (ed.), The Logic of Female Succession: Rethinking Patriarchy and Patrilinearity in Global Perspective (Kyoto, 2003), pp. $53-73$.

9. See Martin Dribe and Christer Lundh, "Retirement as a Strategy for Land Transmission: A Micro Study of Nineteenth Century Rural Sweden", Continuity and Change, 20 (2005), forthcoming; Christer Lundh and Mats Olsson, "The Institution of Retirement on Scanian Estates in the Nineteenth Century", Continuity and Change, I7 (2002), pp. 373-403; David Gaunt, "The Property and Kin Relationships of Retired Farmers in Northern and Central Europe”, in Richard Wall, Jean Robin, and Peter Laslett (eds), Family Forms in Historic Europe (Cambridge, 1983), pp. 249-279; Löfgren, "Family and Household among Scandinavian Peasants".

Io. Dribe and Lundh, "Gender Aspects of Inheritance Strategies".

I r. Winberg, "Familj och jord i tre västgötasocknar"; Dribe and Lundh, "Retirement as a Strategy". 
children's choice of partner. Unmarried women had no authority and were placed in the care of guardians, normally their fathers, who acted on their behalf in marriage negotiations. The institution of guardian is a reflection of the fact that marriage was a matter not only for the young couple, but for their elders too, in particular as far as women were concerned. The law also provided the right to disinherit daughters if they should marry against their parents' wishes. Even sons or widowed daughters could be disinherited if they remarried against the wishes of their parents, because they were part of their parents' household and a refusal to obey could be interpreted as disdain or contempt for their parents. ${ }^{\mathrm{I2}}$

Legislation therefore made it possible for marriages to be based on love, but at the same time, by virtue of their involvement in marriage negotiations and their right to disinherit children who did not obey them, made it possible for parents to influence the choice of a marriage partner. Ethnological researchers have made attempts to create a picture of how this worked in practice, by studying contemporary accounts of the subject.

In older ethnological literature, which dealt mainly with the customs of landed peasants, much emphasis was laid on parental influence on children's marriages and mention was even made of a "parental-power marriage system". ${ }^{13}$ People were reluctant to see the homestead passed on to someone outside the family and wanted instead, as a result of marriage, to increase their own homestead's size by fusion with another one. An advanced expression of that sort of economic planning in connection with marriage was, among other things, the so-called "sibling-exchange" system, in which two siblings from one family married two from another. ${ }^{14}$

Contemporary sources often provide vivid accounts of parental power over children's choice of marriage partner. As mentioned above, it was mostly a matter of marriage strategies among wealthy farmers in southern and central Sweden. Contemporary narrators point out that these farmers endeavoured to marry off their children to their equals, which is to say within the same social group. Wealth and social status, not passion or love, were decisive qualities in the choice of marriage partner. ${ }^{15}$ In I847, Nicolovius, a pseudonym for the parson Nils Lovén, published a description of peasant customs he saw during his childhood at the turn of the century in the district of Skytt in southern Scania in which he stated:

I2. Sveriges rikes lag, Giftobalken (Marriage Act), ch. I: $§ 2, \S 5 ;$ ch. 6: $\S$ I-2.

I3. Rob. K Wikman, quoted in John Granlund, "Bröllopsfunktionärer", Fataburen (I969), pp. I33-I48, quotation p. I34.

14. Marianne Andersson, "Böndernas bönemän", Fataburen (1969), pp. 53-60, 53; Assar Jansson, "Giftermål med syskonbyte under i 700-talet", Rig, 38 (1955), pp. 82-88.

I 5. Eva Wigström, Allmogeseder i Rönnebergs härad på 1840-talet (Malmö, 1985, first pub. I891), pp. 27-28; Nils G. Bruzelius, Allmogelivet i Ingelstads härad i Skåne (Lund, 1976, first pub. I 876$)$, p. 34 . 
Similarity of wealth, but not the way of thinking or opinion, was the basis for marriage unions among farmers' families at the time. Beauty and grace were the least important in making their choice. These concepts did not even have corresponding words in the language of the farmers, and even now, when the word "charming" is used, I hear of a charming horse and even a charming pig, but, so far, never a charming girl. ${ }^{16}$

Marriage is often presented by contemporary narrators as a financial affair, even though that was not openly admitted; and a proposal was a negotiation in accordance with laid-down rules. ${ }^{17}$ In 1976, Nils Bruzelius, a headmaster in the Ingelstad district of southern Scania, published an account of local customs. On marriage he wrote: "In the marriage settlement the most important question was always, "What will you give the girl?' More than one proposal came to an abrupt end at the mere question, because the father-in-law refused to hand over the oxen demanded by the son-in-law." 8

Contemporary narrators compare the peasants' conduct when choosing a marriage partner for their children with the efforts of higher social classes to retain or extend their family property. Whenever those efforts came into conflict with a youngster's love for someone other than the intended partner, or with a lack of affection for a chosen one, parents tried to impose their will and often succeeded. ${ }^{19}$ If opposition from one of the marriage partners to the wishes of parents was too great, it was possible, within the framework of the marriage agreement between two families, to effect a change so that a brother or sister would be offered instead. However, fathers often forced daughters to marry against their will. ${ }^{20}$ Eva Wigström, a teacher and writer describing peasant customs in the district of Rönneberg in western Scania in the I840s, reported: "Just as Denmark has its legends about locked-up maidens, the Scanian rural people had theirs about girls who by force had to marry the men chosen for them by their parents and relatives." ${ }^{21}$ Parents did not have the same jurisdiction to force sons into marriage, and traditional material shows that there were

16. Nicolovius, Folklifwet i Skytts härad i Skåne vid början af detta århundrade (Malmö, I990, first pub. I 847), pp. I 2 I-I 22.

17. Wigström, Allmogeseder $i$ Rönnebergs härad, p. 29.

18. Bruzelius, Allmogelivet i Ingelstads härad, p. 34.

19. Wigström, Allmogeseder i Rönnebergs härad, p. 28; Bruzelius, Allmogelivet i Ingelstads härad, p. 34 .

20. Nils-Arvid Bringéus, Unnarydsborna. Lasses i Lassaberg anteckningar om folklivet i Södra Unnaryd vid I 800-talets början (Stockholm, I967), p. I05. On the initiative of the ethnologist Nils Gabriel Djurklou, Lars Andersson (called Lasse in Lassaberg), who was an active farmer, recorded his notes on peasant life in Unnaryd in Småland, the province north of Scania, during the period I 870 to I 872 . The original manuscript by Lasse in Lassaberg was published in 1967 by Nils-Arvid Bringéus, Professor of Ethnology.

21. Wigström, Allmogeseder i Rönnebergs härad, p. 27. 
instances when boys refused to follow their parents' directions and the parents had to yield. ${ }^{22}$

In addition to these parentally controlled marriages of convenience, there was always room for marriages based on love and affection above all, and in fact the use of parental power to influence children's choice of marriage partners was most evident among the nobility, bourgeoisie, and farmers, where children's marriages had an effect both on the transfer of resources between generations and on the organization of security in old age for parents. ${ }^{23}$ Since parents controlled property, the threat of disinheritance had real significance. For the landless in rural areas, parental influence on children's choice of marriage partner was smaller. ${ }^{24}$

Contemporary accounts show that parental influence on children's marriages was greater in southern Sweden than it was in northern parts of the country, and that might have been due to differences in social structure. In the south, as we have seen, social differences were large and farmers with considerable landholdings gave their daughters large dowries, which is why they had good reason to try to get their children to avoid marrying the "wrong" partner. In the north, the social structure was more egalitarian, which reduced the need for strong parental influence on the choice of marriage partner. ${ }^{25}$

So, ethnological studies based on traditional material emphasize that farmers tried to prevent their children from marrying someone from a landless background. ${ }^{26}$ Even contemporary descriptions call attention to the fact that children of landed peasants usually married their equals. ${ }^{27}$ During the latter half of the eighteenth century there was extensive growth of landless groups. It has been shown that this growth was not due to fertility rates being higher among the landless than among the landed, but to increased downward social mobility. It is probable that, in the process, there was an increase in the proportion of marriages between peasants and the landless. It can also be expected that marriages across social boundaries were more common in areas, for example western Scania, with early proletarianization. Considering that "marrying down" socially was strongly resisted by peasant children, the increased proletarianization of rural areas should have resulted in an alternative strategy of remaining in

22. See Bringéus, Unnarydsborna, p. Ios.

23. Orvar Löfgren, "Från nattfrieri till tonårskultur", Fataburen (1969), pp. 25-52, 35-36; Gunilla Kjellman, Bröllopsgåvan (Lund, 1979); see also Stone, The Family, Sex and Marriage, p. I 82 .

24. Andersson, "Böndernas bönemän", p. 53.

25. Löfgren "Från nattfrieri till tonårskultur", pp. 35-36. For a discussion of the link between dowries and homogamy, see Sabean, Kinship in Neckarhausen, pp. 466-469.

26. Löfgren "Från nattfrieri till tonårskultur", pp. 35-36.

27. Wigström, Allmogeseder $i$ Rönnebergs härad, pp. 27-29; Nicolovius, Folklifwet i Skytts bärad, p. I 2 I; Bruzelius, Allmogelivet i Ingelstads härad, p. 34 . 
the parental home and postponing marriage, or even abstaining from it completely. ${ }^{28}$

Within sociological theories of modernization it is often believed that the nineteenth and early twentieth centuries brought fundamental changes to mating patterns. Industrialization brought not only economic changes that through new employment opportunities for young people reduced parental control over marriage, but also changes of mentality, implying an increased importance of "romantic love" in choosing a marriage partner. ${ }^{29}$ As a result, it is argued that economic factors and family strategies became less important throughout the nineteenth century and that this development ultimately led to increased heterogamy. Empirical studies, however, sometimes find it difficult to substantiate these hypotheses of modernization..$^{\circ}$ Instead, mating patterns, as well as the family system more generally, seem to have been quite robust in resisting the economic and social changes that followed industrialization. ${ }^{3}$

\section{AREA AND DATA}

The data used are based on family reconstitutions carried out within the Scanian Demographic Database ${ }^{32}$ for five rural parishes in western Scania in southern Sweden: Hög, Kävlinge, Halmstad, Sireköpinge, and Kågeröd. They are all about ten kilometres from the coast in the western part of Scania, which is the southernmost province of Sweden (see Figure I). The social structure of these parishes varied somewhat. Hög and Kävlinge were

28. Christer Winberg, Folkökning och proletarisering. Kring den sociala strukturomvandlingen på Sveriges landsbygd under den agrara revolutionen (2nd edn, Lund, 1977), pp. 261-262; Christer Lundh, "Marriage and Economic Change in Sweden during the 18 th and I9th Century", in Isabelle Devos and Liam Kennedy (eds), Marriage and Rural Economy: Western Europe since 1400 (Turnhout, 1999), pp. 217-24I.

29. See in particular William J. Goode, The Family (Englewood Cliffs, NJ, 1964), pp. I08-109; Edward Shorter, The Making of the Modern Family (Glasgow, 1977), pp. I 52-163, 250-262. See also Marco van Leeuwen and Ineke Maas, "Partner Choice and Homogamy in the Nineteenth Century: Was There a Sexual Revolution in Europe?”, Journal of Social History, 36 (2002), pp. IOI-I 23 .

30. See Van Leeuwen and Maas, "Partner Choice and Homogamy".

31. See Michael Anderson, Family Structure in Nineteenth Century Lancashire (Cambridge, 1971); Tamara K. Hareven, Family Time and Industrial Time (Cambridge, I982); Angélique Janssens, Family and Social Change: The Household as a Process in an Industrializing Community (Cambridge, I993).

32. The Scanian Demographic Database is a collaborative project between the Regional Archives in Lund and the Research Group in Population Economics at the Department of Economic History, Lund University. The source material is described in Elisabeth Reuterswärd and Franceska Olsson, "Skånes demografiska databas I646-I894. En källbeskrivning”, Lund Papers in Economic History, 33 (1993), pp. I-62, and the quality of data is analysed in Tommy Bengtsson and Christer Lundh, "Evaluation of a Swedish Computer Program for Automatic Family Reconstitution”, Lund Papers in Economic History, 8 (199I), pp. I-43. 

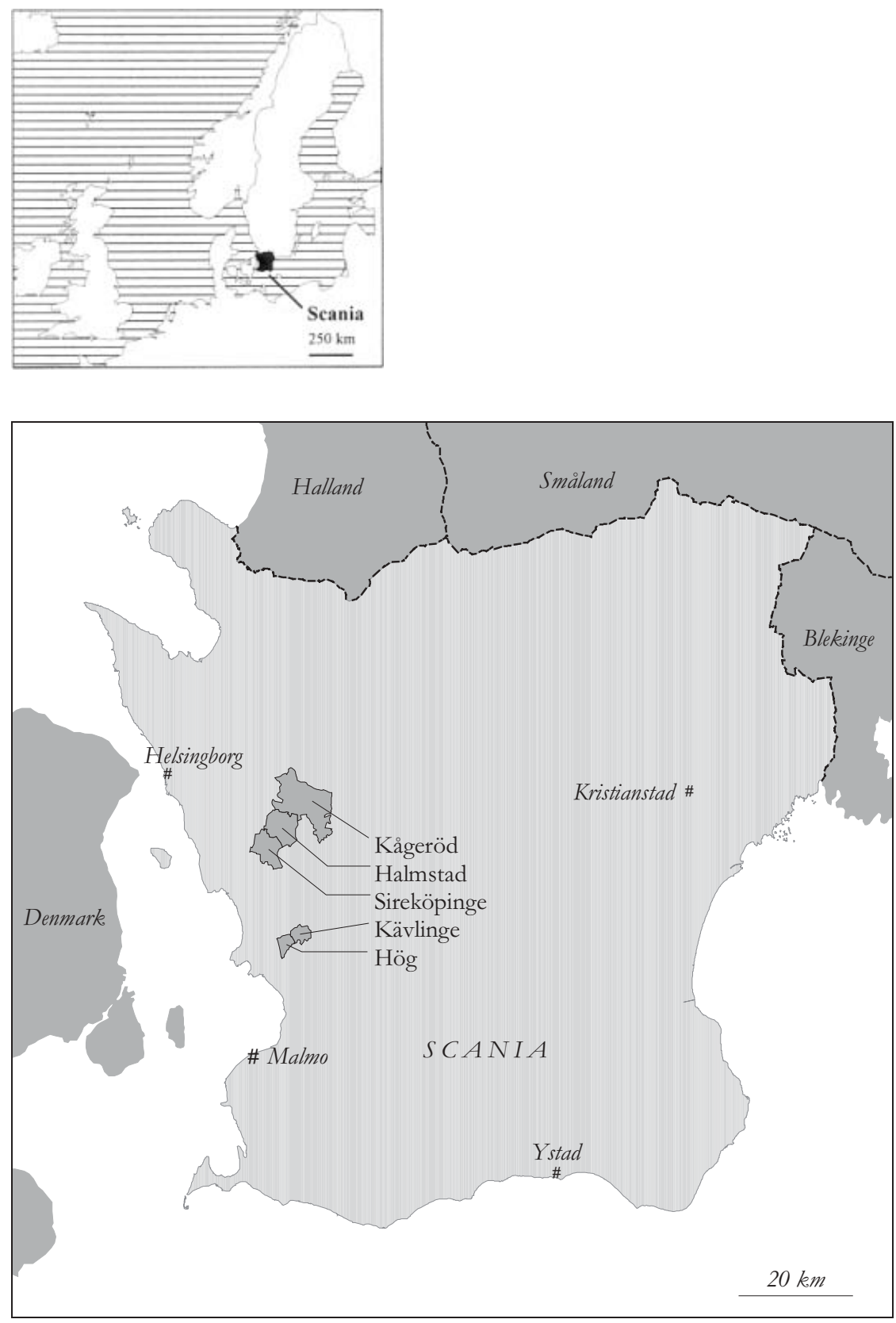

Figure I. Location of the sample of parishes. 
dominated by farmers on freehold and crown land with rather similar social characteristics, while the other three parishes were totally dominated by tenant farmers on manorial land. ${ }^{33}$ Besides the peasant group, the parishes also contained various landless and semi-landless groups, who made their living working for other people. In I 830, the five parishes had 3,978 inhabitants. By I 895 that figure had increased to 5,539: an average annual increase of 0.5 per cent during this 65 -year period, a somewhat slower rate of growth than for rural Sweden as a whole during the same period, which was 0.6 per cent per year. ${ }^{34}$

The family reconstitutions were carried out using data for births, marriages and deaths for the period from the late seventeenth century until I 894. The material is of high quality. The reconstitutions were carried out automatically using a computer programme. ${ }^{35}$ They have also been checked manually and linked to other sources, chiefly poll-tax registers (mantalslängder) and the catechetical examination registers (busförbörslängder). The database contains all individuals born in the different parishes, or migrating into them. Instead of sampling any particular group (a birth cohort for example) each individual is followed from birth, or time of arrival in the parish, to death, or migration out again.

Since this study deals with mating behaviour, we need information on the social background of both spouses in a given couple. In the period I 829-I894, 4,040 married couples were counted in the 5 parishes under investigation. From them we sampled the couples for whom the social origin of both husband and wife could be established.

One potential problem with family reconstitution studies is that migration can lead to a family's demographic events being spread over several different parishes. Depending on how we deal with this problem, results derived from family reconstitution data may be biased in various ways. ${ }^{36}$ In this study we are dependent on information about conditions in the parental home of individuals living in marital unions in the parishes. Using traditional family reconstitution data would have forced us to limit

33. See Martin Dribe, Leaving Home in a Peasant Society: Economic Fluctuations, Household Dynamics and Youth Migration in Southern Sweden, I829-I866 (Lund/Södertälje, 2000).

34. Statistics Sweden, Befolkningsutvecklingen under 250 år. Historisk statistik för Sverige (Stockholm, 1999), p. 42.

35. See Bengtsson and Lundh, "Evaluation of a Swedish Computer Program".

36. See Steven Ruggles, "Migration, Marriage and Mortality: Correcting Sources of Bias in English Family Reconstitution I 580-1837”, Population Studies, 46 (1992), pp. 507-522; idem, "The Limitations of English Family Reconstitution: English Population History from Family Reconstitution I580-1837", Continuity and Change, I4 (1996), pp. 105-130; E.A. Wrigley, "The Effect of Migration on the Estimation of Marriage Age in Family Reconstitution Studies", Population Studies, 48 (1994), pp. 8I-97; Sune Akerman, "An Evaluation of the Family Reconstitution Technique”, Scandinavian Economic History Review, 25 (1977), pp. I60-170; Poul Thestrup, "Methodological Problems of a Family Reconstitution Study in a Danish Parish Before I800", Scandinavian Economic History Review, 20 (1972), pp. I-26. 
the sample to couples where both husband and wife were born in the same parish they resided in after marriage. Due to very high rates of migration in this area, ${ }^{37}$ such an approach would be likely to suffer from selection bias because the sample couples would have been taken from among nonmigrants, who, most probably, would therefore have been selected by reference to landholding, physical ability, and so forth..$^{3}$

To avoid that problem, we have traced all married individuals back to their parish of birth, regardless of whether their marriages took place in the parish of residence or not, and added information about their fathers' social status at birth. Information about the occupations of fathers was taken from the birth records or, if available, the catechetical examination registers, and data on access to land or croft were taken from poll-tax registers. ${ }^{39}$ In that way we obtained information about the social origin of both husband and wife in married couples without introducing too much selection bias stemming from migration. However, due to missing or incorrect information about date and place of birth in the registers, we were not able to link data on the parental home to all individuals in the sample. For about 30 per cent of the couples we lack information about the social origin of either husband or wife, sometimes both, which leaves us with 2,724 couples for whom we have data on the social background of both husband and wife.

Table I overleaf shows couples distributed by spouses' social origin according to the HISCLASS classification..$^{\circ}$ Since the area of investigation in this study is entirely rural, for practical reasons, some minor regrouping within the HISCLASS framework has to be undertaken. Classes I-5 ("managers and professionals") must be excluded from the analysis, since these groups are too small to be analysed by themselves, as is evident from Table I, and too different to be conflated with any of the other groups.

In the present context "skilled workers" (classes 6-7) consists only of

37. See Dribe, Leaving Home; idem, "Migration of Rural Families in I 9 th Century Southern Sweden: A Longitudinal Analysis of Local Migration Patterns", History of the Family, 8 (2003), pp. 247-265; Martin Dribe and Christer Lundh, "People on the Move: Determinants of Servant Migration in Nineteenth Century Sweden", Continuity and Change, 20 (2005), pp. 53-91.

38. See Dribe, Leaving Home, ch. 2 for a discussion.

39. Information on individual birthplaces was gathered from the catechetical examination registers. The data were linked as part of the research project "Early-Life Conditions, Social Mobility, and Longevity", headed by Tommy Bengtsson and financed by the US National Institutes of Health/National Institute of Ageing (IPor AG I 83 I4-02), the Swedish Council for Social Research, and the Bank of Sweden Tercentenary Foundation. For details on the source material see Dribe, Leaving Home, ch. 2.

40. M.H.D. van Leeuwen and I. Maas, "HISCLASS", paper presented at the 5 th European Social Science History Conference (Berlin, 24-27 March 2004). This classification is based on the more detailed occupational classification in HISCO; see Marco H.D. van Leeuwen, Ineke Maas, and Andrew Miles, HISCO: Historical International Standard Classification of Occupations (Leuven, 2002). 


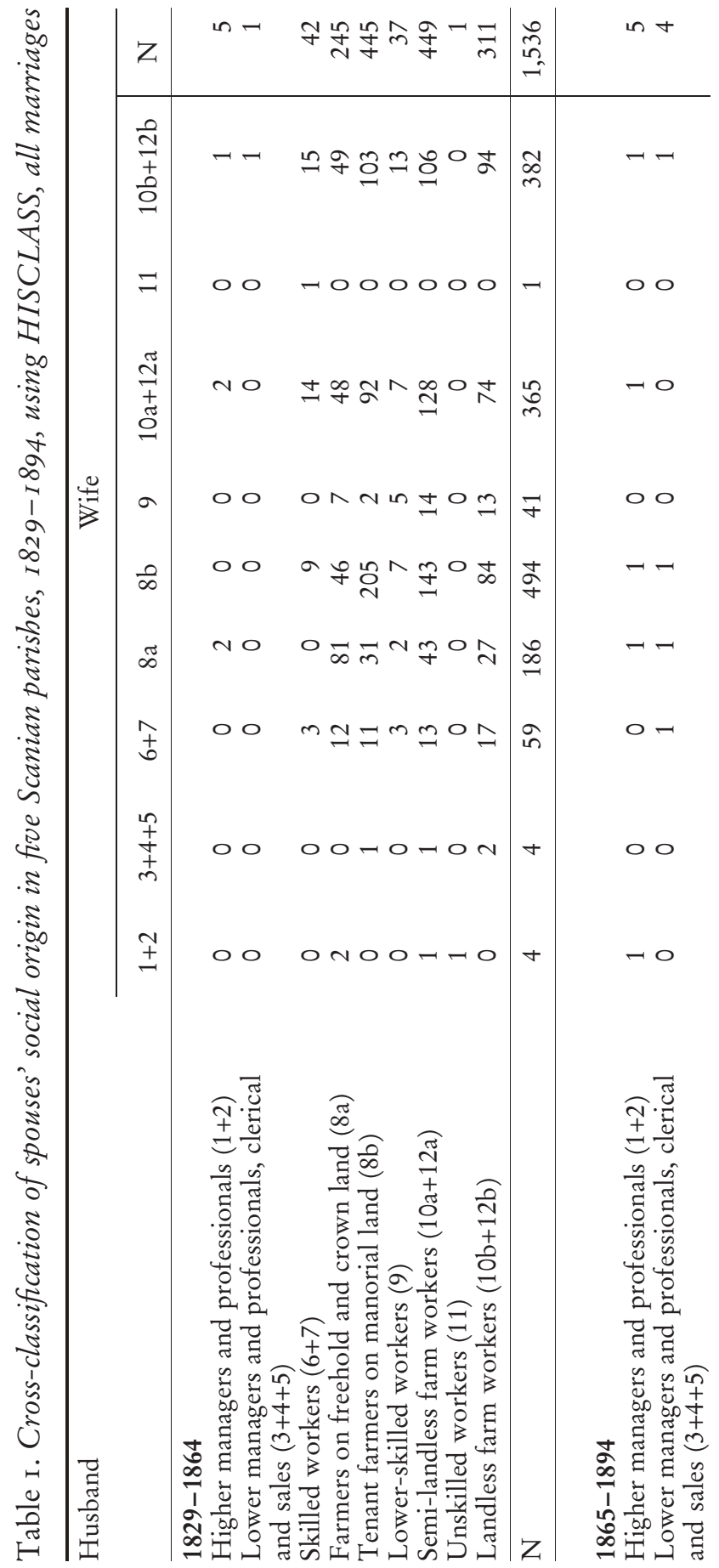




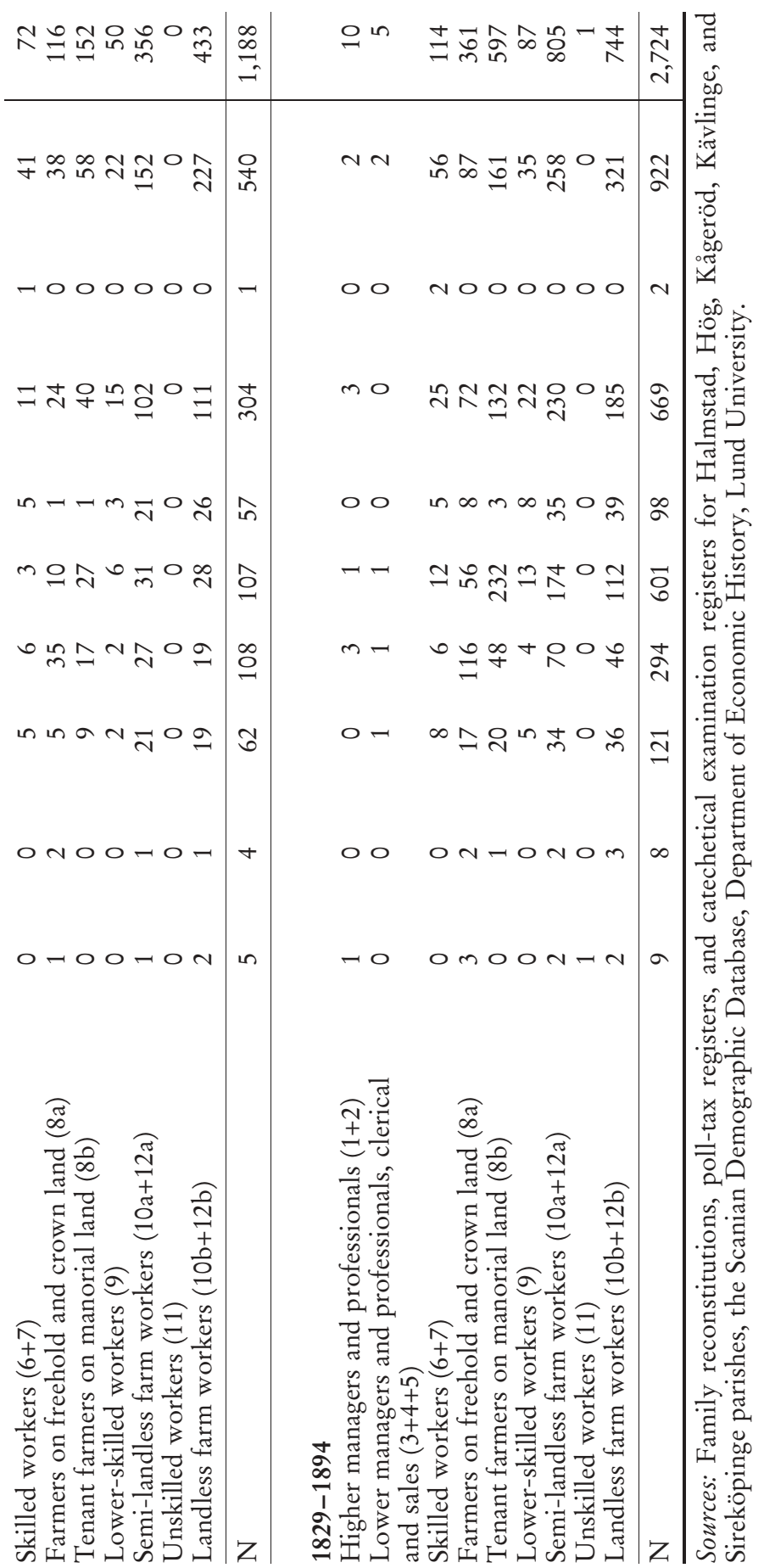


artisans, such as shoemakers, tailors, or carpenters; in a rural environment such as the parishes under study, artisans were not specialized skilled workers as were urban artisans, for whom both education and establishment were controlled by the guilds. ${ }^{4}$ Rural artisans often worked for different peasants in the parish, rather than in their own workshops like urban artisans; sometimes they even lived in a peasant household while doing the work. Usually they were unable to live by their trade alone but had to work as farm labourers to supplement their income, and in the historical sources the same person might easily be recorded as a shoemaker one year and a landless worker another. Hence, rural artisans are grouped together with landless farm workers in this analysis.

The class of farmers (8) is divided into two subgroups by reference to their type of property rights and land tenure. Class $8 \mathrm{a}$ consists of farmers on freehold and crown land who had at least enough land at their disposal to provide for their families and to pay land rents or taxes..$^{22}$ Freeholders owned their land and paid land taxes, while crown tenants farmed land belonging to the Crown and paid land rent for it. Although there were important differences between those groups, for example when it came to inheritance and subdivision of land, ${ }^{43}$ their situations were in many respects closely similar, especially if we compare them with other social groups. Consequently, in this analysis they will be analysed together and hereafter be jointly referred to as farmers. ${ }^{44}$

Class $8 \mathrm{~b}$ consists of tenant farmers on manorial land with holdings above subsistence level. They were part of a manorial system and their conditions differed both socially and legally in important respects from

4I. For a detailed analysis of rural artisans, see Carl-Johan Gadd, Självbushäll eller arbetsdelning? Svenskt lant- och stadshantverk ca I400-I860 (Gothenburg, I99I).

42. We have used I/I6 mantal as the limit of subsistence. Mantal is an old tax unit, originally meaning "the number of men". During the sixteenth century, every landholding was supposed to constitute one mantal, i.e. be large enough to support one peasant and his family as well as produce a surplus to be paid as tax to the crown. With few exceptions, this was indeed the case during the sixteenth century. Thus, at this time a mantal simply meant that the peasant had land and was supposed to pay tax to the crown. However, due to repeated subdivisions of landholdings, farmsteads typically got smaller and smaller fractions of a mantal assigned to them. Furthermore, reclamation of new land, as well as changed methods of cultivation, led to increased land productivity, which makes a comparison over time of the size of different farms almost impossible. Nevertheless, the mantal can be used at least as a rough measure of the size of a farm relative to other farms in the village in the same period. Thus, by comparing the different mantal peasants had, the relative productive potential of the landholdings can be determined. See Dribe, Leaving Home, pp. 26-27. It has been calculated that in the Harjager district, where Hög and Kävlinge are situated, one mantal was equivalent to about 200 acres in I820. See Emil Sommarin, Det skanska jordbrukets ekonomiska utveckling I80I-I9I4, vols 2-3 (Lund, 1939), p. 25 .

43. See Dribe and Lundh, "Gender Aspects of Inheritance Strategies"; Carl-Johan Gadd, Den agrara revolutionen $1700-1870$. Det svenska jordbrukets historia, band 3 (Stockholm, 2000).

44. See also Dribe, Leaving Home, ch. 2. 
those of farmers on freehold and crown land. At least up to the i 860 s they paid most of their rent as labour rent, working on the demesne. Often the exact amount of labour to be paid was not specified in contracts. ${ }^{45}$ After the I860s, the manorial system changed towards more specific contracts and less labour rent, which made conditions between the different farming groups more similar. From contemporary descriptions we also know that freeholders in the area generally looked down on tenants, despite the fact that they often farmed land of equal size. ${ }^{46}$

Class 9, "lower-skilled workers", consists of soldiers. The organization of the Swedish military system meant that the local community put at the disposal of a soldier a cottage or croft, with a small garden plot, in exchange for military service. He was given some payment too, usually in a combination of cash and benefits in kind, but the wage was not sufficient to live off, so the soldier had to work as a labourer to earn some more. In any case, being a soldier was by no means a full-time job, for usually a man spent only a couple of weeks with the army, during the off season for agriculture. The remainder of the year he spent at home, and worked on the land. ${ }^{47}$ Accordingly, in this analysis, soldiers are merged into the group of landless farm workers.

The class of farm workers ( $\mathrm{I} O$ and $\mathrm{I} 2$ ) is also divided into two subgroups. The "landless" includes farm workers without access to land, i.e. contract workers (statare), day labourers, servants, and lodgers ( $10 \mathrm{~b}$ and I 2b): the "semi-landless" ( Ioa and I 2a) consists of occupational groups who often had access to some land. Here we find peasants with land below subsistence level as well as of cottagers (gatebusmän) and crofters (torpare), who sometimes had landholdings equal to that of smallholding peasants, but frequently had only small garden plots. Unfortunately, it is impossible to distinguish in the sources between cottagers and crofters with and without arable land, which makes the semi-landless group somewhat heterogeneous, containing peasants and cottagers/crofters with land below subsistence level, as well as some cottagers and crofters lacking arable land altogether. Finally, the group of unskilled (non-farm) workers (I I ) is very small, which is only to be expected since the area under study was completely rural until the last decades of the nineteenth century.

Because of the small number of observations in some of these categories and the difficulty in distinguishing different occupations in this rural context, either from the sources or from the actual work individuals performed, an example being that artisans and soldiers were farm labourers most of the time, we chose a less detailed social categorization in order to

45. See Mats Olsson, Storgodsdrift. Godsekonomi och arbetsorganisation i Skäne frän dansk tid till mitten av I 800-talet (Lund/Stockholm, 2002).

46. See Wigström, Allmogeseder i Rönnebergs härad.

47. See Lars Ericson, Svenska knektar. Indelta soldater, ryttare och båtsmän $i$ krig och fred (Lund, 2002). 
arrive at meaningful interpretations of the patterns of homogamy. Four different groups will be analysed: farmers on freehold and crown land (hereafter called "farmers"), tenants on manorial land (hereafter called "tenants"), "semi-landless", and "landless". The first two groups are identical to class $8 \mathrm{a}$ and $8 \mathrm{~b}$ respectively, while the semi-landless group is the same as class roa+i 2a. In the landless group classes 6, 7, 9, rob, i I, and $\mathrm{I} 2 \mathrm{~b}$ are merged together.

In the Malthusian situation of eighteenth- and early nineteenth-century rural Sweden resources were scarce and so access to marriage varied between social groups. Since the social norm was that a marriage should result in the building of a separate household, a pre-condition for marriage was that along with a secure income access be available to a dwelling suitable for a family. Compared with youths of landless and semi-landless origin, the children of farmers and tenants were favoured in this respect and they were generally younger when they married, men being about thirty and women twenty-seven. ${ }^{4}$ Young people of non-peasant origin often had to work as servants for a longer time and on average married a year or two older.

In the second half of the nineteenth century a substantial decrease occurred in mean age at first marriage for non-peasants, for women a drop of two or three years and for men two years. The average marriage age of peasants did not change much though, and in the late nineteenth century the difference was small between social groups. One interpretation of the decrease in the mean age at first marriage of the non-peasant group is that it reflected the social transformation in the countryside. Population pressure and the commercialization of agriculture perhaps gave rise to new employment and housing circumstances for married people such as crofters, cottagers and contract workers (statare), so access to marriage for landless people probably became easier and they could marry younger. ${ }^{49}$

Total marital fertility for women over twenty was around $7 . .^{50}$ In the mid-nineteenth century about two-thirds of all newborn children survived to their thirtieth birthday, which implies that usually more than one potential heir was available when farms were transferred and that the choice of successor was consequently not a trivial decision. ${ }^{\text {I }}$

48. Christer Lundh, "Swedish Marriages: Custom, Legislation and Demography in the Eighteenth and Nineteenth Centuries", Lund Papers in Economic History, 88 (2003), p. 50. Recalculation of means for $1740-1849$ and 1850-1894 from the data in figures 7 and 8 respectively.

49. Ibid., pp. 49-5 I.

50. The figure refers to the period $1766-1865$ in the same area; see Tommy Bengtsson and Martin Dribe, "Agency, Social Class, and Fertility in Southern Sweden I766-1865", in George Alter, Noriko O. Tsuya, and Wang Feng (eds), Prudence and Pressure (forthcoming), ch. 4. 51. Calculated from period life tables for Sweden I 846-1850, Statistics Sweden, Befolkningsutvecklingen under 250 år. Historisk statistik för Sverige (Stockholm, 1999), pp. I I9-I20. See 
A special problem with family reconstitution data is that for inwardmigrating couples we do not know whether one or both spouses was remarried, or married for the first time. This distinction can be made only for couples married in any of the five parishes under examination here. In cases of remarriage, it was noted in the marriage record if either spouse had been married before. In our sample both first marriages and remarriages are included (a total of 2,693 couples). In order to make clear whether or not the pattern of mate selection is different for spouses marrying for the first time, a smaller sample of first marriages is studied ( $\mathrm{I}, 374$ couples), the latter sample considered because it could highlight possible differences in homogamy which might depend on the marital status of spouses when the marriage itself was entered into. On the other hand, we are well aware that results may be biased, since this population is selected on the basis of the couple marrying and settling down in the area of investigation.

\section{MEASURING AND MODELLING HOMOGAMY}

Tables 2 and 3 present the number of couples distributed by reference to the social origin of the spouses. In Table 2 all marriages are included, while Table 3 includes only first marriages. In these cross-classification tables, homogamous unions are counted in the diagonal cells. As can be seen in these tables, the number in the diagonal cell is larger than the rest of the numbers in the respective rows or columns for farmers, tenants, and landless, which is an indication of positive assortative mating.

Given the four-group occupational classification used here, total homogamy over the entire period I829-1894 was about 40 per cent in the two populations studied (see Table 4). Comparing the two periods it seems that homogamy became if anything stronger over time, but the differences between the periods are rather small ( 38 and 39 per cent in the first period and 44 and 42 per cent in the second). Table 5 indicates that for the whole period I 829-I894, the percentage of males who were married to a social equal was higher for landless and tenants and lower for semilandless and farmers. For landless and tenants, homogamy was also stronger among males than among females, while the opposite was true for farmers and semi-landless. While homogamy was more pronounced in the first period for individuals of tenant origin, the opposite was true for individuals of landless background. These tendencies counterbalanced each other, which may help to explain why no changes could be observed in total homogamy over time.

Tables 4 and 5 indicate the occurrence of homogamy in the rural population we are studying. However, to compare the preference for

also Dribe and Lundh, "Retirement as a Strategy for Land Transmission"; idem, "Gender Aspects of Inheritance Strategies". 
Table 2. Cross-classification of spouses' social origin in five Scanian parishes, I829-I 894, all marriages

\begin{tabular}{lrrrr|r}
\hline Husband & \multicolumn{4}{c}{ Wife } \\
\cline { 2 - 6 } & Farmers & Tenants & $\begin{array}{c}\text { Semi- } \\
\text { landless }\end{array}$ & Landless & N \\
\hline 1829-1864 & 81 & 46 & 48 & 68 & 243 \\
Farmers & 31 & 205 & 92 & 116 & 444 \\
Tenants & 43 & 143 & 128 & 133 & 447 \\
Semi-landless & 29 & 100 & 95 & 164 & 388 \\
Landless & 184 & 494 & 363 & 481 & 1,522 \\
\hline N & 35 & 10 & 24 & 44 & 113 \\
\hline 1865-1894 & 17 & 27 & 40 & 68 & 152 \\
Farmers & 27 & 31 & 102 & 194 & 354 \\
Tenants & 27 & 37 & 137 & 351 & 552 \\
Semi-landless & 106 & 105 & 303 & 657 & 1,171 \\
Landless & & & & & \\
\hline N & 116 & 56 & 72 & 112 & 356 \\
\hline 1829-1894 & 48 & 232 & 132 & 184 & 596 \\
Farmers & 70 & 174 & 230 & 327 & 801 \\
Tenants & 56 & 137 & 232 & 515 & 940 \\
Semi-landless & 290 & 599 & 666 & 1138 & 2,693 \\
Landless & & & & & \\
\hline N & & & & & \\
\hline Source: See & & & & & \\
\hline
\end{tabular}

Source: See Table I.

homogamous marriage among the separate occupational groups, or over time, we must take into consideration their social structure. Not only must we analyse absolute homogamy, but relative homogamy too, and one possible way to approach the latter is log-linear analysis.

Log-linear analysis has been widely used to model cross-classification count data of the kind available to us here..$^{2}$ Log-linear models have often been used, for instance, in analysing social mobility, ${ }^{53}$ but also in analyses of

52. See Leo A. Goodman, "On the Measurement of Social Mobility: An Index of Status Persistence", American Sociological Review, 34 (1969), pp. 831-850; Leo A. Goodman, "Multiplicative Models for the Analysis of Occupational Mobility Tables and Other Kinds of Cross-Classification Tables", American Journal of Sociology, 84 (1979), pp. 804-8 I 9.

53. For examples in historical research see Jan van Bavel, Hilde Peeters, and Koen Matthijs, "Connections between Intergenerational and Marital Mobility: A Case Study, Leuven, I830I910", Historical Methods, 3 I (1998), pp. I22-I 34; Marco van Leeuwen and Ineke Maas, "Loglinear Analysis of Changes in Mobility Patterns: Some Models with an Application to the Amsterdam Upper Classes in the Second Half of the Nineteenth Century", Historical Methods, 24 (199I), pp. 66-79; Frans van Poppel, Jurjen de Jong, and Aart C. Liefbroer, "The Effects of Paternal Mortality on Son's Social Mobility: A Nineteenth-Century Example”, Historical Methods, 3 I (1998), pp. IоI-I I2. 
Table 3. Cross-classification of spouses' social origin in five Scanian parishes, I829-I894, first marriages

\begin{tabular}{|c|c|c|c|c|c|}
\hline \multirow[t]{2}{*}{ Husband } & \multicolumn{5}{|c|}{ Wife } \\
\hline & Farmers & Tenants & Semi-landless & Landless & $\mathrm{N}$ \\
\hline \multicolumn{6}{|l|}{ 1829-1864 } \\
\hline Farmers & 36 & 13 & 20 & 21 & 90 \\
\hline Tenants & 13 & 131 & 51 & 58 & 253 \\
\hline Semi-landless & 22 & 86 & 70 & 71 & 249 \\
\hline Landless & 17 & 60 & 51 & 69 & 197 \\
\hline $\mathrm{N}$ & 88 & 290 & 192 & 219 & 789 \\
\hline \multicolumn{6}{|l|}{$1865-1894$} \\
\hline Farmers & 14 & 4 & 14 & 18 & 50 \\
\hline Tenants & 5 & 19 & 19 & 52 & 95 \\
\hline Semi-landless & 14 & 21 & 41 & 94 & 170 \\
\hline Landless & 10 & 15 & 75 & 170 & 270 \\
\hline $\mathrm{N}$ & 43 & 59 & 149 & 334 & 585 \\
\hline \multicolumn{6}{|l|}{ 1829-1894 } \\
\hline Farmers & 50 & 17 & 34 & 39 & 140 \\
\hline Tenants & 18 & 150 & 70 & 110 & 348 \\
\hline Semi-landless & 36 & 107 & 111 & 165 & 419 \\
\hline Landless & 27 & 75 & 126 & 239 & 467 \\
\hline $\mathrm{N}$ & 131 & 349 & 341 & 553 & 1,374 \\
\hline
\end{tabular}

Source: See Table I.

Table 4. Total homogamy

\begin{tabular}{lcclcc}
\hline & \multicolumn{2}{c}{ All marriages } & & \multicolumn{2}{c}{ First marriages } \\
\cline { 2 - 3 } \cline { 5 - 6 } & $\begin{array}{c}\text { Couples } \\
\text { (per cent) }\end{array}$ & $\mathrm{N}$ & & $\begin{array}{c}\text { Couples } \\
\text { (per cent) }\end{array}$ & $\mathrm{N}$ \\
\hline Total homogamy & 41 & 2,693 & & 40 & 1,374 \\
$1829-1864$ & 38 & 1,522 & & 39 & 789 \\
$1865-1894$ & 44 & 1,171 & & 42 & 585 \\
\hline
\end{tabular}

Source: See Table I.

Note: Total homogamy $=$ total number of couples where both spouses had the same social origin expressed as a percentage of the total number of couples.

mating patterns both in historical and contemporary populations. ${ }^{54}$ In loglinear analysis the count in the cells of a cross-classification table is modelled multiplicatively. In the simplest case - what is usually referred to as the "independence model" - the count in a cell is assumed to depend only on the marginal distributions in the table:

54. See Matthijs Kalmijn, "Status Homogamy in the United States", American Journal of Sociology, 97 (I99I), pp. 496-523; idem, "Assortative Mating by Cultural and Economic 
Table 5. Homogamous males and females

\begin{tabular}{|c|c|c|c|c|c|c|c|c|}
\hline & \multicolumn{4}{|c|}{ All marriages } & \multicolumn{4}{|c|}{ First marriages } \\
\hline & \multicolumn{2}{|c|}{ Males } & \multicolumn{2}{|c|}{ Females } & \multicolumn{2}{|c|}{ Males } & \multicolumn{2}{|c|}{ Females } \\
\hline & $\%$ & $\mathrm{~N}$ & $\%$ & $\mathrm{~N}$ & $\%$ & $\mathrm{~N}$ & $\%$ & $\mathrm{~N}$ \\
\hline \multicolumn{9}{|l|}{$1829-1864$} \\
\hline Farmers & 33 & 243 & 44 & 184 & 40 & 90 & 41 & 88 \\
\hline Tenants & 46 & 444 & 41 & 494 & 52 & 253 & 45 & 290 \\
\hline Semi-landless & 29 & 447 & 35 & 363 & 28 & 249 & 36 & 192 \\
\hline Landless & 42 & 388 & 34 & 481 & 35 & 197 & 32 & 219 \\
\hline \multicolumn{9}{|l|}{ 1865-1894 } \\
\hline Farmers & 31 & 113 & 33 & 106 & 28 & 50 & 33 & 43 \\
\hline Tenants & 18 & 152 & 26 & 105 & 20 & 95 & 32 & 59 \\
\hline Semi-landless & 29 & 354 & 34 & 303 & 24 & 170 & 28 & 149 \\
\hline Landless & 64 & 552 & 53 & 657 & 63 & 270 & 51 & 334 \\
\hline \multicolumn{9}{|l|}{$1829-1894$} \\
\hline Farmers & 33 & 356 & 40 & 290 & 36 & 140 & 38 & 131 \\
\hline Tenants & 39 & 596 & 39 & 599 & 43 & 348 & 43 & 349 \\
\hline Semi-landless & 29 & 801 & 35 & 666 & 26 & 419 & 33 & 341 \\
\hline Landless & 55 & 940 & 45 & 1138 & 51 & 467 & 43 & 553 \\
\hline
\end{tabular}

Source: See Table I.

$$
\ln \left(f_{i j}\right)=u+b_{i}+w_{j}
$$

where $u$ is the grand mean, $b_{i}$ is the row effects (social structure of husbands), $w_{j}$ is the columns effects (social structure of wives). If this model fits the observed data there is nothing structuring the mating process except the availability of spouses of different social origins, so the mating process itself is completely random. This model will be included only for comparisons. The modelling strategy will be to identify a number of theoretically relevant models which can be tested and compared. Since we are interested in studying homogamy over time we have divided the sample into two different time periods (see Table 2 above). The first model to test is the independence model taking into account changes in social structure over time, which is done both by including a parameter for time period, and interaction terms between time period and row and column effects. This model can then be compared with different homogamy models.

Occupational Status", American Journal of Sociology, I00 (1994), pp. 422-452; Robert D. Mare, "Five Decades of Educational Assortative Mating", American Sociological Review, 56 ( 1991 ), pp. I 5-32; Robert McCaa, "Isolation or Assimilation? A Log Linear Interpretation of Australian Marriages, 1947-60, 1975, and 1986”, Population Studies, 43 (1989), pp. I55-162; Bart Van de Putte, "Homogamy by Geographical Origin: Segregation in Nineteenth-Century Flemish Cities (Gent, Leuven, and Aalst)", Journal of Family History, 28 (2003), pp. 364-390; Van Leeuwen and Maas, "Partner Choice and Homogamy". 
Table 6 presents an overview of the different models. As already mentioned, the independence model assumes that there are no systematic differences between the different cells in the table, which will be used for comparison. The equal homogamy model assumes that people have a tendency to marry homogamously, i.e. to marry someone from the same social group, and that this tendency does not differ between social groups. In other words, all social groups are equally likely to marry someone from the same social group.

In the case of pre-industrial rural society we expect the mating process to be different in different social groups. Landholding peasants, and especially farmers on freehold and crown land, can be expected to have wanted to marry homogamously in response to the importance to them of access to land in securing social status. The landless, on the other hand, cannot be expected to have preferred to marry, for financial reasons at least, other landless people. On the contrary, marrying a landholding peasant would imply upward social mobility. Of course, some may have been forced to marry a landless spouse from lack of alternatives, but we may still expect to find differences between social groups in the strength of their tendency to homogamy. The differential homogamy model allows for different homogamy effects in different social groups.

Sometimes it is argued that the main social difference in pre-industrial rural society was between the landed and the non-landed, while differences were much smaller within those groups. 55 In order to test this hypothesis we use a land homogamy model, which has one parameter for peasants marrying peasants, and one for non-peasants marrying non-peasants.

Since partner choice was intimately connected with social mobility, marrying upward (hypergamy) was most probably a goal desired by many of the landless and semi-landless. It could be argued that it should have been easier for women to marry upward, since they were not the managers of farms, while a farmer son in the process of taking over the family farm might have been more inclined to marry a spouse of landless origin, since there could be no transfer to her of responsibility over the farm. It is also possible that parents might look more favourably upon such a match for their son than if their daughter were to marry a landless man, who would then, in effect, become manager of the farm. In order to test that hypothesis we use three different hypergamy models: one model with a separate parameter each for males and females marrying upward, one model for women marrying upward and one for men marrying upward.

55. See Ingrid Eriksson and John Rogers, Rural Labor and Population Change: Social and Demographic Developments in East-Central Sweden during the Nineteenth Century (Uppsala, 1978), pp. 57-64. For demographic evidence see Bengtsson and Dribe, "Agency, Social Class, and Fertility"; Dribe, Leaving Home; Martin Dribe and Christer Lundh, "Husmäns och torpares demografi i 8 I - I 865", in Kerstin Sundberg and Christer Lundh (eds), Gatebus och gatehusfolk i skånska godsmiljöer (Lund, 2002), pp. I43-156. 
Table 6. Models of homogamy

\begin{tabular}{|c|c|c|c|c|}
\hline \multicolumn{5}{|c|}{ Independence } \\
\hline \multirow[t]{2}{*}{ Husband } & \multicolumn{4}{|c|}{ Wife } \\
\hline & FA & $\mathrm{TE}$ & SL & LL \\
\hline FA & 0 & 0 & 0 & 0 \\
\hline TE & 0 & 0 & 0 & 0 \\
\hline SL & 0 & 0 & 0 & 0 \\
\hline LL & 0 & 0 & 0 & 0 \\
\hline \multicolumn{5}{|c|}{ Equal homogamy (d) } \\
\hline \multirow[t]{2}{*}{ Husband } & \multicolumn{4}{|c|}{ Wife } \\
\hline & FA & $\mathrm{TE}$ & SL & LL \\
\hline FA & d & 0 & 0 & 0 \\
\hline $\mathrm{TE}$ & 0 & d & 0 & 0 \\
\hline SL & 0 & 0 & d & 0 \\
\hline LL & 0 & 0 & 0 & $\mathrm{~d}$ \\
\hline
\end{tabular}

Differential homogamy $\left(\mathrm{d}_{\mathrm{k}}\right)$

\begin{tabular}{lcccc}
\hline Husband & \multicolumn{5}{c}{ Wife } \\
\cline { 2 - 5 } & FA & TE & SL & LL \\
\hline FA & $\mathrm{d}_{1}$ & 0 & 0 & 0 \\
TE & 0 & $\mathrm{~d}_{2}$ & 0 & 0 \\
SL & 0 & 0 & $\mathrm{~d}_{3}$ & 0 \\
LL & 0 & 0 & 0 & $\mathrm{~d}_{4}$ \\
\hline
\end{tabular}

Land homogamy $\left(\mathrm{c}_{\mathrm{m}}\right)$

\begin{tabular}{lcccc}
\hline Husband & \multicolumn{5}{c}{ Wife } \\
\cline { 2 - 5 } & FA & TE & SL & LL \\
\hline FA & $\mathrm{c}_{1}$ & $\mathrm{c}_{1}$ & 0 & 0 \\
TE & $\mathrm{c}_{1}$ & $\mathrm{c}_{1}$ & 0 & 0 \\
SL & 0 & 0 & $\mathrm{c}_{2}$ & $\mathrm{c}_{2}$ \\
LL & 0 & 0 & $\mathrm{c}_{2}$ & $\mathrm{c}_{2}$ \\
\hline
\end{tabular}

Hypergamy* $\left(\mathrm{h}_{\mathrm{n}}\right)$

\begin{tabular}{lcccc}
\hline Husband & \multicolumn{5}{c}{ Wife } \\
\cline { 2 - 5 } & $\mathrm{FA}$ & $\mathrm{TE}$ & $\mathrm{SL}$ & $\mathrm{LL}$ \\
\hline FH & 0 & $\mathrm{~h}_{1}$ & $\mathrm{~h}_{1}$ & $\mathrm{~h}_{1}$ \\
NT & $\mathrm{h}_{2}$ & 0 & $\mathrm{~h}_{1}$ & $\mathrm{~h}_{1}$ \\
SL & $\mathrm{h}_{2}$ & $\mathrm{~h}_{2}$ & 0 & $\mathrm{~h}_{1}$ \\
LL & $\mathrm{h}_{2}$ & $\mathrm{~h}_{2}$ & $\mathrm{~h}_{2}$ & 0
\end{tabular}




\begin{tabular}{|c|c|c|c|c|}
\hline \multicolumn{5}{|c|}{ Female hypergamy* $\left(\mathrm{h}^{\mathrm{f}}\right)$} \\
\hline \multirow[t]{2}{*}{ Husband } & \multicolumn{4}{|c|}{ Wife } \\
\hline & FA & $\mathrm{TE}$ & SL & LL \\
\hline FA & 0 & $\mathrm{~h}^{\mathrm{f}}$ & $h^{f}$ & $h^{f}$ \\
\hline $\mathrm{TE}$ & 0 & 0 & $\mathrm{~h}^{\mathrm{f}}$ & $h^{f}$ \\
\hline SL & 0 & 0 & 0 & $\mathrm{~h}^{\mathrm{f}}$ \\
\hline LL & 0 & 0 & 0 & 0 \\
\hline \multicolumn{5}{|c|}{ Male hypergamy* $\left(\mathrm{h}^{\mathrm{m}}\right)$} \\
\hline \multirow[t]{2}{*}{ Husband } & \multicolumn{4}{|c|}{ Wife } \\
\hline & FA & $\mathrm{TE}$ & SL & LL \\
\hline FA & 0 & 0 & 0 & 0 \\
\hline $\mathrm{TE}$ & $\mathrm{h}^{\mathrm{m}}$ & 0 & 0 & 0 \\
\hline SL & $\mathrm{h}^{\mathrm{m}}$ & $\mathrm{h}^{\mathrm{m}}$ & 0 & 0 \\
\hline LL & $\mathrm{h}^{\mathrm{m}}$ & $\mathrm{h}^{\mathrm{m}}$ & $\mathrm{h}^{\mathrm{m}}$ & 0 \\
\hline
\end{tabular}

FA $=$ Farmers

$\mathrm{TE}=$ Tenants

$\mathrm{SL}=$ Semi-landless

$\mathrm{LL}=$ Landless

* Marrying upward

The next step is to compare the different models. Different tests are available to check the fit of each model. ${ }^{56}$ The most commonly used is the likelihood ratio test of the null hypothesis that the model fits the data: high values of the test statistic (the deviance statistic, $G^{2}$ ) indicate a poor fit and significance levels below 0.05 testify that the model does not fit the data, which in itself can give useful information about mating strategy. For example, a rejection of the independence model implies that the mating process is not random, but that there are some underlying structures determining who marries whom.

Nested models can be compared using a similar test where the difference in the deviance statistics between the two models is $\chi^{2}$-distributed under the null hypothesis of no difference between a larger and a smaller model, with the degrees of freedom equal to the difference in the number of parameters estimated.57 There is also an alternative way of comparing models that does not require models to be nested, namely the Bayesian Information Criterion (BIC):

56. For a description of log-linear models see Alan Agresti, An Introduction to Categorical Analysis (New York, 1996); Daniel Zelterman, Advanced Log-Linear Models Using SAS (Cary, NC, 2002).

57. Nested models are built hierarchically so that a larger model contains the same variables as the smaller model with some additional variables. In most cases statistical tests devised for model comparisons, such as the likelihood ratio test, require models to be nested in this way. 


$$
B I C=G^{2}-d f \log (N)
$$

where $G^{2}$ is the deviance statistic (the likelihood ratio test statistic), $d f$ the degree of freedom, and $N$ the number of observations. A model with a lower BIC is preferred, and models with a negative BIC can be considered to have a reasonable fit. ${ }^{8}$ Table 7 displays the fifteen different models estimated and the statistics used for model check. ${ }^{59}$

As expected, the independence model is clearly rejected (the critical value for $G^{2}$ at the 0.01 level with 25 degrees of freedom is 54.9), which shows that the mating process is not random. Taking into account the changed social structure (model 3) significantly improves the model fit, but the model is still rejected. In fact only the differential homogamy model has a reasonable fit, as shown both by the BIC and the likelihood ratio test (p-value>0.I). The differential homogamy model which controls for changes over time is not preferred to the one which does not control for period differences, which suggests that the pattern of homogamy did not change significantly between the two time periods. There seems to be no difference in which of the two models is preferred between the sample of all married couples and the sample of first marriages. These comparisons show that the data are best described by a model controlling for changes over time in the social structure and allowing homogamy to differ between all social groups.

Apparently the marriage pattern was characterized by a high degree of homogamy, but the strength of it differed among social groups, and an analysis of the estimated parameters $\left(d_{k}\right)$ can inform us more exactly how homogamy differed among different groups. Table 8 shows the parameter estimates for the period as a whole and for each of the separate subperiods. In the latter case, the coefficients shown in the table are the net effects calculated from the estimated interaction model (model 7), and the $\mathrm{p}_{\text {interac. }}$ is the p-values for the interaction effects. The coefficients show the effects of the diagonal parameter on $\ln \left(f_{i j}\right)$ in each period while the exponentiated coefficients show the effect on the expected count $\left(f_{i j}\right):$ a value of 2 implies that the estimated count in the cell is twice as high as could be expected taking into consideration only the marginal distributions (social structure).

In panel $\mathrm{A}$ of Table 8, farmers show the strongest homogamy with an effect of about 5, which indicates that cases of farmer marrying farmer are more than five times as frequent as could be expected from a random match, controlling for changed social status over time. Tenants show a weaker tendency, but still quite powerful, and the landless have a statistically significant homogamy effect, albeit lower than for tenants.

58. See Adrian E. Raftery, "Choosing Models for Cross-Classifications", American Sociological Review, 5I(1986), pp. I45-I46.

59. Model estimations were made using the GENMOD procedure in SAS. For log-linear models in SAS, see Zelterman, Advanced Log-Linear Models. 
Table 7. Model comparisons

\begin{tabular}{|c|c|c|c|c|c|c|c|}
\hline & \multirow[t]{2}{*}{ Model } & \multicolumn{3}{|c|}{ All marriages } & \multicolumn{3}{|c|}{ First marriages ${ }^{+}$} \\
\hline & & $G^{2}$ & $d f$ & $B I C$ & $G^{2}$ & $d f$ & $B I C$ \\
\hline 1 & $\begin{array}{l}\text { Independence } \\
\left(b_{i}, w_{j}\right)\end{array}$ & 756.5 & 25 & 669.8 & 435.9 & 25 & 349.2 \\
\hline 2 & $\begin{array}{l}\text { Time difference } \\
\left(b_{i}, w_{j}, t\right)\end{array}$ & 710.6 & 24 & 627.4 & 405.5 & 24 & 322.3 \\
\hline 3 & $\begin{array}{l}\text { Changed social structure } \\
\left(b_{i}, w_{j}, t, b_{i}^{*} t, w_{j}^{*} t\right)\end{array}$ & 236.5 & 18 & 174.1 & 141.8 & 18 & 79.4 \\
\hline 4 & $\begin{array}{l}\text { Equal homogamy } \\
\left(b_{i}, w_{j}, t, h_{i}^{*} t, w_{j}^{*} t, d\right)\end{array}$ & 100.9 & 17 & 42.0 & 86.3 & 17 & 27.4 \\
\hline 5 & $\begin{array}{l}\text { Equal homogamy, time } \\
\text { difference } \\
\left(b_{i}, w_{j}, t, b_{i}^{*} t, w_{j}^{*} t, d, d^{*} t\right)\end{array}$ & 98.4 & 16 & 42.9 & 83.1 & 16 & 27.6 \\
\hline 6 & $\begin{array}{l}\text { Differential homogamy } \\
\left(b_{i}, w_{j}, t, h_{i}^{*} t, w_{j}^{*} t, d_{k}\right)\end{array}$ & $11.9 *$ & 14 & -36.6 & $15.2 *$ & 14 & -33.4 \\
\hline 7 & $\begin{array}{l}\text { Differential homogamy, time } \\
\text { diff. } \\
\left(b_{i}, w_{j}, t, b_{i}^{*} t, w_{j}^{*} t, d_{k}{ }^{*} t\right)\end{array}$ & $10.9 *$ & 10 & -23.8 & $13.1 \%$ & 10 & -21.6 \\
\hline 8 & $\begin{array}{l}\text { Land homogamy } \\
\left(h_{i}, w_{j}, t, h_{i}^{*} t, w_{j}^{*} t, c_{m}\right)\end{array}$ & 159.6 & 17 & 100.7 & 110.1 & 17 & 51.2 \\
\hline 9 & $\begin{array}{l}\text { Land homogamy, time diff. } \\
\left(h_{i}, w_{j}, t, h_{i}^{*} t, w_{j}^{*} t, c_{m}, c_{m}{ }^{*} t\right)\end{array}$ & 151.2 & 16 & 95.7 & 108.4 & 16 & 53.0 \\
\hline 10 & $\begin{array}{l}\text { Hypergamy } \\
\left(b_{i}, w_{j}, t, b_{i}^{*} t, w_{j}^{*} t, b_{n}\right)\end{array}$ & 99.0 & 16 & 43.5 & 84.6 & 16 & 29.1 \\
\hline 11 & $\begin{array}{l}\text { Hypergamy, time diff. } \\
\left(b_{i}, w_{j}, t, h_{i}^{*} t, w_{j}^{*} t, h_{n}, h_{n}{ }^{*} t\right)\end{array}$ & 95.5 & 14 & 47.0 & 81.0 & 14 & 32.4 \\
\hline 12 & $\begin{array}{l}\text { Female hypergamy } \\
\left(b_{i}, w_{j}, t, b_{i}^{*} t, w_{j}^{*} t, h^{f}\right)\end{array}$ & 127.2 & 17 & 68.2 & 93.7 & 17 & 34.8 \\
\hline 13 & $\begin{array}{l}\text { Female hypergamy, time diff. } \\
\left(b_{i}, w_{j}, t, b_{i}^{*} t, w_{j}^{*} t, b^{f *} t\right)\end{array}$ & 124.6 & 16 & 69.1 & 92.4 & 16 & 37.0 \\
\hline 14 & $\begin{array}{l}\text { Male hypergamy } \\
\left(b_{i}, w_{j}, t, h_{i}^{*} t, w_{j}^{*} t, h^{m}\right)\end{array}$ & 158.2 & 17 & 99.3 & 112.0 & 17 & 53.1 \\
\hline 15 & $\begin{array}{l}\text { Male hypergamy, time diff. } \\
\left(b_{i}, w_{j}, t, b_{i}^{*} t, w_{j}^{*} t, b^{m}, b^{m *} t\right)\end{array}$ & 158.1 & 16 & 102.6 & 109.4 & 16 & 53.9 \\
\hline
\end{tabular}

Source: See Table I.

+ Only marriages recorded in the parishes.

* $\mathrm{p}>0 . \mathrm{I}$, which implies that the model cannot be rejected at the ro per cent level. All other models can be rejected below the 5 per cent level of significance.

$b_{i}$ husband's social origin (row effects).

$w_{j}$ wife's social origin (column effects).

$t$ time period (I829-I864, I 865-I894).

For explanations of other parameters see Table 6.

Only in the case of the semi-landless can we find no indication of homogamy. Most probably that is explained by the fact that this group is quite heterogeneous, including both smallholders and virtually landless cottagers - groups that can be expected to have married in opposite 


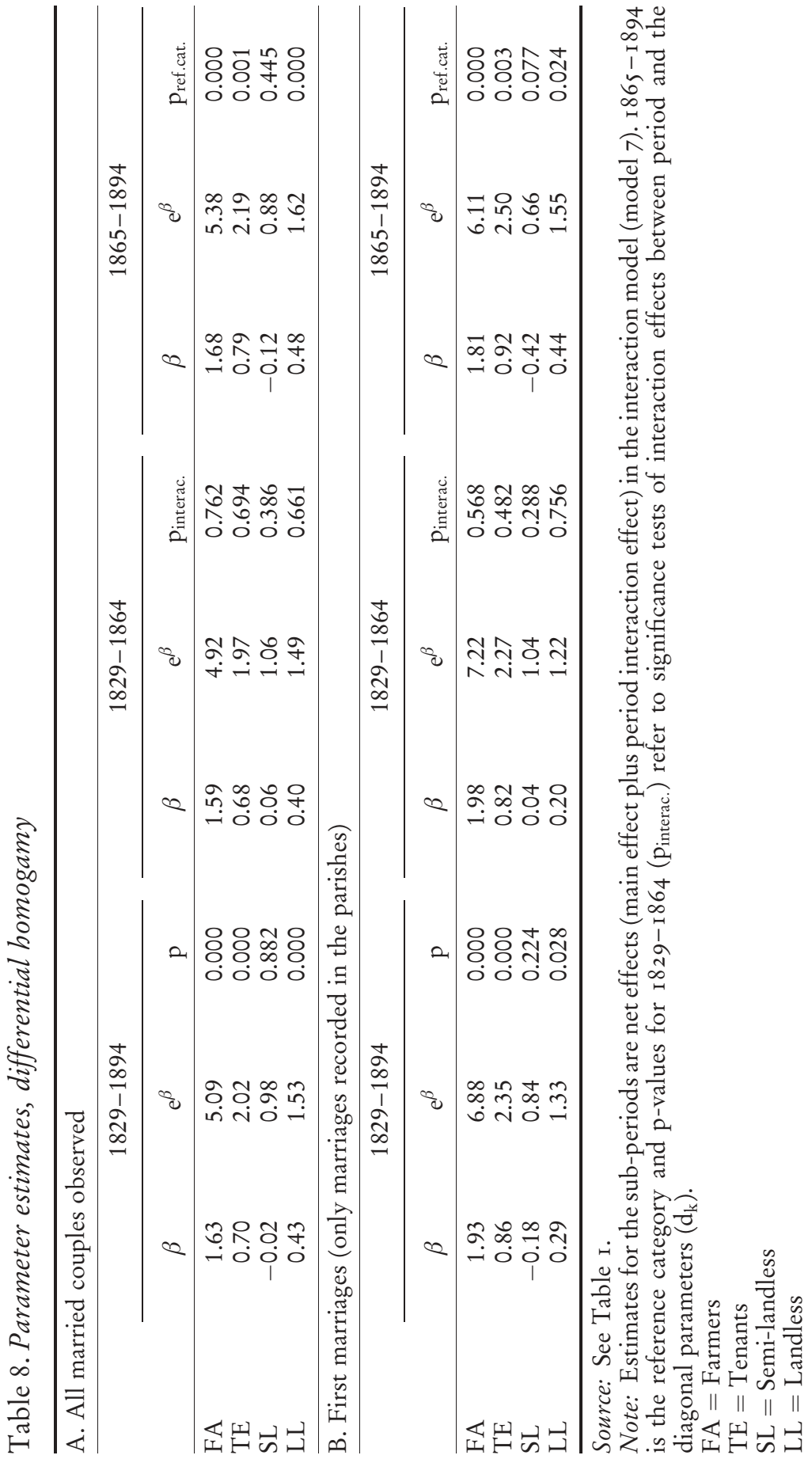


directions. Apart from the semi-landless there seems to be a clear hierarchy in homogamy, with farmers being clearly the most homogamous, tenants taking the middling position, and the landless being least homogamous. Looking at panel $\mathrm{B}$, it is clear that the same hierarchy applies to couples in their first marriages: the only noteworthy difference between the whole sample and the sample of first marriages is that homogamy among farmers is even stronger when only first marriages are considered.

These results are quite as expected. Landholding farmers had most to risk in the mating game and most to gain by marrying a like individual. Consequently they showed the strongest homogamy. It also seems reasonable that homogamy in this group was stronger in first marriages, partly because parental control over first marriages was greater, partly because of higher availability of potential spouses of similar social status among never married individuals than would be found among widows or widowers. Migration-related selectivity could be at work here, too. We know that farmers showed lower mobility than the landless or semilandless ${ }^{60}$ and it may be that those children of farmers chosen to take over the family holding were even less likely to move, which would contribute to the stronger likelihood of homogamy we have observed in first marriages among farmers.

Turning to changes over time, none of the interaction terms is statistically significant, which implies that we cannot show any clear changes in the pattern of homogamy over time; that was also the conclusion drawn from the model comparisons in Table 7. If we consider the estimated effects there seems to be a strengthening of homogamy among farmers when looking at all marriages, but a weakening when we look only at first marriages. For the semi-landless there is a tendency to heterogamy over time, as indicated by the negative coefficient relating to the second period. For the other social groups the differences between the periods are small. Taken together, the data suggest that homogamy remained strong during the entire period, which does not support hypotheses of fundamental change in mating patterns over the nineteenth century such as are envisaged by modernization theories: at least, not in rural areas.

\section{CONCLUSION}

Finding the right partner was a crucial thing for many people in preindustrial society. Marriage was not only an act of love but a financial transaction as well. That is especially true for landowning peasants (farmers and tenants), since they had most to risk from a bad match.

60. Dribe, Leaving Home; idem, "Migration of Rural Families". 
Parental control over marriage was strong, but peasant children themselves anyway preferred a partner from a similar background. Most probably, the economic concern was only one reason for preferring homogamy. More intangible aspects related to differences in social status, while selfidentification with one's own group also contributed. Ethnological evidence and contemporary accounts give many examples of the importance of such perceived differences between social groups in preindustrial rural Sweden.

In this article we have studied quantitatively the pattern of homogamy in a rural community in southern Sweden during the nineteenth century a period with quite dramatic economic and social changes following agricultural transformation. The results show a society characterized by a relatively strong tendency towards homogamy. Given the occupational classification in this study, about 40 per cent of couples were homogamous unions. However, homogamy was not uniform across social groups. Farmers were considerably more homogamous than landless labourers, with tenants taking a middle position. Only the semi-landless did not show any homogamy at all, in that they were no more likely than could be expected from the observed social structure to marry someone from the same social origin, which can probably be explained by the fact that this was a heterogeneous group positioned between the landed groups and landless labourers.

Homogamy was also stronger for first marriages, especially among farmers, probably as a result of more parental control and a larger supply of potential marriage partners than in cases of remarriage. Interestingly, mating patterns remained fairly constant over time. Despite this being a period of quite rapid changes in Swedish society, homogamy did not weaken. Apparently, the choice of marriage partner remained an important financial and social concern, which does not support ideas in the literature that changes following modernization in the mentality or structure of opportunity for young people implied a transition to a more heterogamous society in which love replaced economics as the driving force in the choice of partner.

The rather strong homogamy characterizing landowning peasants in particular makes perfectly good sense in the light of the economic realities of peasants in a rural society. The landless, on the other hand, did not have much reason to marry within their group, since marrying a farmer or a tenant would be a major step up the social ladder. Instead, the homogamy we observe in this group is to a large extent a function of the preference for homogamy in the landed group; in most cases there were simply no alternatives for the landless except to marry other landless people. ${ }^{61}$ The 
profound economic changes during the nineteenth century following agricultural transformation and early industrialization did not change that situation. If anything, homogamy among farmers became stronger, testifying that mating habits were part of a very slowly changing structure which was deeply rooted in rural society. 